\title{
Upregulation of P2RX7 in Cx3cr1-Deficient Mononuclear Phagocytes Leads to Increased Interleukin- $1 \beta$ Secretion and Photoreceptor Neurodegeneration
}

\author{
Shulong J. Hu, ${ }^{1,2,3}$ Bertrand Calippe, ${ }^{1,2,3}$ @Sophie Lavalette, ${ }^{1,2,3}$ Christophe Roubeix, ${ }^{1,2,3}$ Fadoua Montassar, ${ }^{1,2,3}$ \\ Michael Housset, ${ }^{1,2,3}$ Olivier Levy, ${ }^{1,2,3}$ Cecile Delarasse, ${ }^{4}$ Michel Paques, ${ }^{1,2,3,5}$ OJosé-Alain Sahel, $, 1,2,3,5$ \\ Florian Sennlaub, ${ }^{1,2,3 *}$ and $\odot$ Xavier Guillonneau ${ }^{1,2,3 *}$ \\ ${ }^{1}$ INSERM, U 968, Paris F-75012, France, ${ }^{2}$ Sorbonne Universités, UPMC Univ Paris 06, UMR S 968, Institut de la Vision, Paris, F-75012, France, ${ }^{3}$ CNRS, \\ UMR 7210, Paris, F-75012, France, ${ }^{4}$ INSERM U 1127, CNRS UMR 7225, Sorbonne Universités, UPMC Univ Paris 06 UMR S 1127, Institut du Cerveau et de \\ la Moelle épinière, ICM, Paris F-75013, France, and ${ }^{5}$ Centre Hospitalier National d'Ophtalmologie des Quinze-Vingts, DHU ViewMaintain, INSERM-DHOS \\ CIC 1423, Paris, F-75012, France
}

Photoreceptor degeneration in age-related macular degeneration (AMD) is associated with an infiltration and chronic accumulation of mononuclear phagocytes (MPs). We have previously shown that Cx3cr1-deficient mice develop age- and stress- related subretinal accumulation of MPs, which is associated with photoreceptor degeneration. $C x 3 \mathrm{cr} 1$-deficient MPs have been shown to increase neuronal apoptosis through IL- $1 \beta$ in neuroinflammation of the brain. The reason for increased IL- $1 \beta$ secretion from $C x 3 c r 1$-deficient MPs, and whether IL- $1 \beta$ is responsible for increased photoreceptor apoptosis in $C x 3 \mathrm{cr} 1$-deficient mice, has not been elucidated. Here we show that CX3cr1-deficient MPs express increased surface P2X7 receptor (P2RX7), which stimulates IL-1 $\beta$ maturation and secretion. P2RX7 and IL- $1 \beta$ inhibition efficiently blunted $C x 3 \mathrm{cr} 1$-MP-dependent photoreceptor apoptosis in a monocyte/retina coculture system and in lightinduced subretinal inflammation of $C x 3 c r 1$-deficient mice in vivo. Our results provide an explanation for increased CX3CR1-dependent IL- $1 \beta$ secretion and suggest that IL-1 $\beta$ or P2RX7 inhibition can help inhibit the inflammation-associated photoreceptor cell loss in late $\mathrm{AMD}$, including geographic atrophy, for which no efficient treatment currently exists.

Key words: IL-1; inflammasome; monocytes; P2RX7; retina

\section{Introduction}

Mononuclear phagocytes (MPs) comprise a family of cells that include inflammatory monocytes (Mos), macrophages (M $\phi \mathrm{s})$, and resident macrophages such as microglial cells (Chow et al., 2011). Circulating inflammatory Mos express low levels of CX3CR1, whereas microglial cells express high levels of CX3CR1 (Geissmann et al., 2003; Wolf et al., 2013). Following infection or injury, inflammatory Mos are recruited to the tissue from the circulation and differentiate into $\mathrm{M} \phi \mathrm{s}$. These recruited $\mathrm{M} \phi \mathrm{s}$ show a pro-inflammatory phenotype in the early stages of inflammation. If the inflammatory $\mathrm{M} \phi$ response is not quickly controlled, it can contribute to disease progression, in particular in tissues with low regenerative capacities such as the brain or the

Received Sept. 23, 2014; revised Jan. 29, 2015; accepted March 6, 2015.

Author contributions:S.J.H., B.C., F.S., and X.G. designed research;S.J.H., B.C., S.L., C.R., F.M., M.H., O.L., C.D., F.S., and X.G. performed research; S.J.H. contributed unpublished reagents/analytic tools; S.J.H., B.C., S.L., C.R., F.M., M.H., O.L., C.D., M.P., J.-A.S., F.S., and X.G. analyzed data; S.J.H., F.S., and X.G. wrote the paper.

This work was supported by grants from INSERM, ANR "blanc" (A05120DD), ANR Maladies Neurologiques et Psychiatriques (ANR-08-MNPS-003), ANR Geno 2009 (R09099DS), Labex Lifesenses, Carnot, ADPS-ALLIANZ, and ERC starting Grant (ERC-2007 St.G. 210345).

*F.S. and X.G. contributed equally to this work.

The authors declare no competing financial interests.

Correspondence should be addressed to Xavier Guillonneau, Institut de la Vision, Paris F-75012, France. E-mail: xavier.guillonneau@inserm.fr.

DOI:10.1523/JNEUROSCI.3955-14.2015

Copyright $\odot 2015$ the authors $\quad 0270-6474 / 15 / 356987-10 \$ 15.00 / 0$ eye (Streilein, 2003; Ransohoff, 2009; Conductier et al., 2010). Throughout the CNS, neurons constitutively express proteins such as CX3CL1 to suppress activation of CX3CR $1^{\text {high }}$ microglial cells (Cardona et al., 2006; Galea et al., 2007; Wolf et al., 2013). The suppression of CX3CL1/CX3CR1 tonic inhibitory signal can lead to increased MP accumulation and neuronal degeneration in models of Parkinson's disease and amyotrophic lateral sclerosis (Cardona et al., 2006).

Age-related macular degeneration (AMD) is the leading cause of irreversible blindness in the industrialized world (Klein et al., 2004). Geographic atrophy (GA), a clinical form of late AMD, is characterized by a slowly expanding lesion of the retinal pigment epithelium (RPE) and photoreceptor (Sarks, 1976). Physiologically, the subretinal space, located between the RPE and the photoreceptor outer segments (POSs), is devoid of significant numbers of MPs. However, MPs accumulate in the subretinal space in GA (Gupta et al., 2003; Combadiére et al., 2007), including inflammatory Mos (Sennlaub et al., 2013). Genetic or pharmacological inhibition of inflammatory Mo recruitment strongly inhibits photoreceptor degeneration in models of photo-oxidative stress (Rutar et al., 2012; Sennlaub et al., 2013), in the $A b c a 4^{-/-} R d h 8^{-/-}$mouse Stargardt/AMD model (Kohno et al., 2013), in a carboxyethylpyrrole immunizationinduced AMD model (Cruz-Guilloty et al., 2013), and in rd10 mice (Guo et al., 2012). Similarly, we showed that subretinal MPs 
observed in age- and light-challenged $C \times 3 \mathrm{cr} 1$-deficient mice are in part $(50 \%)$ derived from inflammatory Mos, which were mainly responsible for the observed photoreceptor degeneration (Sennlaub et al., 2013). However, the molecular mediators of inflammatory Mo-associated photoreceptor death are not characterized.

The Il-1 $\beta$ gene is transcribed after pro-inflammatory stimuli, such as TLR activation, and encodes for the pro-IL- $1 \beta$ protein (Allan et al., 2005; Simi et al., 2007). Activation by a second stimulus, such as the P2X7 receptor (P2RX7) by extracellular ATP, can trigger the assembly of the NLRP3 inflammasome, activation of the caspase- 1 that cleaves IL- $1 \beta$ precursor and produces mature, secretable IL-1 $\beta$ (Schroder and Tschopp, 2010). IL- $1 \beta$ expression is increased in the CNS in acute and chronic neurodegenerative diseases (Shaftel et al., 2008). Growing evidence suggests that inhibiting IL- $1 \beta$-induced inflammation greatly reduced neuronal cell death in models of acute injury and age-related neurodegenerative diseases (Shaftel et al., 2008). Similarly, Cardona et al. (2006) demonstrated that the increased neurotoxicity observed in $C x 3 \mathrm{cr} 1$-deficient mice was attributable to increased release of IL- $1 \beta$ from $C \times 3 \mathrm{cr}^{\text {GFP/GFP }}$-MPs. However, the reason for increased IL- $1 \beta$ release from $C \times 3 c r 1^{G F P / G F P}$-MPs has not been elucidated.

\section{Materials and Methods}

Animals. Breeding pairs of $C x 3 c r 1^{\text {GFP/GFP }}$ (Stock number 008451) and $P 2 r x 7^{-1-}$ (Stock number 005576) mice were obtained from The Jackson Laboratory. Wild-type (C57BL/6J) mice were purchased from Janvier at the age of 10 weeks. All mice used in this study were $r d 8$ mutation free. Both male and female mice were used in this study. All animals were housed in pathogen-free conditions at the animal facilities in a $12 \mathrm{~h}$ light/dark (100-500 lux) cycle with water and normal diet food available ad libitum. All experimental protocols and procedures were approved by the local animal care committee Comité d'ethique en experimentation animale Charles Darwin (No. 00156.02).

Light-challenge model. Two- to three-month-old mice were adapted to darkness for $6 \mathrm{~h}$ and pupils were fully dilated with $1 \%$ atropine (Novartis). Animals were then exposed to green LED light (4500 lux; Jean Paul Vezon Équipements) for $4 \mathrm{~d}$ and subsequently kept in cyclic $12 \mathrm{~h}$ light/dark normal animal conditions until they were killed. For some experiments, mice were treated with intravitreal injections (IVT) of $2 \mu \mathrm{l}$ Brilliant Blue G (BBG; Sigma-Aldrich) $(25 \mathrm{mg} / \mathrm{l})$ or IL-1Ra (kineret; 150 $\mathrm{mg} / \mathrm{ml}$ ) at days 3 and 7 . MP accumulation at days $1,3,4,10$, and 14 was evaluated on IBA1-stained retinal and choroidal/RPE flat mounts. For each eye, IBA1 MPs were counted on whole RPE/choroidal flat mounts and on the outer segment side of the retina. Photoreceptor degeneration was quantified at days 5 and 10 after light exposure on TUNEL retinal flat mounts.

Retinal flat mount preparation. Immunohistochemistry on retinal/ choroidal flat mounts was conducted as previously described (Sennlaub et al., 2013). Briefly, mice were killed by $\mathrm{CO}_{2}$ asphyxiation and enucleated. The globes were fixed in $4 \%$ PFA for $30 \mathrm{~min}$, then rinsed in $1 \times \mathrm{PBS}$, $\mathrm{pH}$ 7.3. Retinal and RPE/choroid tissues were dissected intact from the globe, flat mounted, and processed for immunohistochemistry using the following primary antibody: polyclonal rabbit anti-P2RX7 (APR-008; Alomone Labs), polyclonal rabbit anti-IL-1 $\beta$ (ab9722; Abcam), and polyclonal goat anti-IBA1 (ab5076; Abcam).

Secondary antibodies included donkey anti-rabbit and anti-goat antibodies conjugated with Alexa Fluor 488 and 546 (Life Technologies). Staining with Hoechst (1:1000), a nuclear marker, was also used. Flat mount images were captured with a DM5500 microscope (Leica) and analyzed by MetaMorph software (Molecular Devices).

Isolation of murine bone marrow monocytes. Bone marrow monocytes (BMMs) were harvested from 3- to 4-month-old Cx3crl ${ }^{\text {GFP/GFP }}$ and $\mathrm{C} 57 \mathrm{BL} / 6 \mathrm{~J}$ mice killed by $\mathrm{CO}_{2}$ inhalation. BMMs were flushed from femurs and tibiae with PBS containing 10\% fetal bovine serum. BMMs were negatively selected by magnetic sorting following the protocol suggested by the manufacturer (EasySep Mouse Monocyte Enrichment Kit; Stemcell Technologies).

Briefly, the mouse monocyte enrichment mixture is designed to enrich mouse monocytes from mouse bone marrow by depletion of T-cells, B-cells, NK cells, dendritic cells, progenitors, granulocytes, and red blood cells using a combination of biotinylated monoclonal antibodies directed against these cell-surface antigens. Unwanted cells were specifically labeled with dextran-coated magnetic particles using biotinylated antibodies against cell-surface antigens expressed on the unwanted cells. Magnetically labeled cells were then separated from unlabeled target cells by using a magnet. The enriched cells were then resuspended in X-VIVO 15 (Lonza) at $3 \times 10^{6}$ cells $/ \mathrm{ml}$. The purity of the BMMs was assayed by flow cytometry using CD11b, LY6C, and LY6G markers. The CD11b ${ }^{+}$

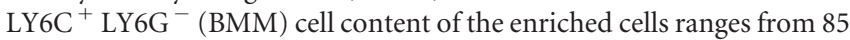
to $95 \%$. The rest of the enriched cells are usually CD11b ${ }^{+} \mathrm{LY}_{6 \mathrm{G}}{ }^{+}$cells (neutrophils).

BMM cell culture. BMMs from three to four animals were pooled and resuspended at equal concentration in X-VIVO 15 medium (Lonza) containing L-glutamine $2 \mathrm{~mm}$ and penicillin/streptomycin $50 \mathrm{U} / \mathrm{ml}$ (Life Technologies), plated in 96-well plates and incubated in $37^{\circ} \mathrm{C}, 5 \% \mathrm{CO}_{2}$ atmosphere. After $2 \mathrm{~h}$, non-adherent cells were removed. BMMs were then treated with LPS (Escherichia coli 0111:B4; Sigma-Aldrich), POSs from porcine retina prepared as previously described (Molday and Molday, 1987), benzoylbenzoyl ATP (BzATP; Sigma-Aldrich), BBG (SigmaAldrich), and IL-1Ra (Kineret).

Reverse transcription and real-time PCR. Real-time (RT)-PCR was used to measure mRNA expression levels of Il-1 $\beta, P 2 r x 7, C d 206$, and Il-1 ra (primer sequences available upon request). Total RNA was extracted from the sorted BMMs using the NucleoSpin RNA XS (740902; Macherey-Nagel) according to the manufacturer's instructions and converted to cDNA using oligo (dT) as primer and Superscript II (Life Technologies). Each RT assay was performed in a $20 \mu \mathrm{l}$ reaction. Subsequent RT-PCR was performed using cDNA, Sybr Green PCR Master Mix (4309155; Life Technologies), and specific primer $(0.5 \mathrm{pmol} / \mu \mathrm{l})$. RTPCR was performed using the Applied Biosystems StepOne Real-Time PCR systems with the following profile: $10 \mathrm{~min}$ at $95^{\circ} \mathrm{C}$, followed by a total of 40 two-temperature cycles $\left(15 \mathrm{~s}\right.$ at $95^{\circ} \mathrm{C}$ and $1 \mathrm{~min}$ at $\left.60^{\circ} \mathrm{C}\right)$. To verify the purity of the products, a melting curve was produced after each run according to the manufacturer's instructions. Results were expressed as fold induction after normalization by Rps26.

ELISA. Retinal extracts from PBS-perfused mice (light-challenge model) and BMM supernatants were collected and IL- $1 \beta$ was measured by ELISA (DY401; R\&D Systems) as described by the manufacturer. Briefly, 96-well plates (Nalge Nunc) were coated overnight at RT with a purified rat anti-mouse IL- $1 \beta \mathrm{mAb}$. Samples and a seven-point standard curve obtained by twofold serial dilutions of purified recombinant mouse IL-1 $\beta$ (R\&D Systems) were added to the 96-well plates after washing and blocking. Total IL- $1 \beta$ binding was detected using biotinylated goat anti-mouse IL- $1 \beta \mathrm{mAb}$ (R\&D Systems), followed by streptavidin$\mathrm{HRP}$ and tetramethylbenzidine as substrate. Analysis was performed on the Infinite M1000 (Tecan). All measurements were done in duplicate. Optical density was determined at $450 \mathrm{~nm}$.

Cell-surface P2RX7 protein detection by flow cytometry. C57BL/6J- and $C \times 3 c^{\text {GFP/GFP }}$-BMMs were incubated in PBS medium (blocking buffer) containing 2 mм EDTA (Sigma-Aldrich), 3\% FCS, 3\% normal rat serum, and 2\% mouse Seroblock (anti-CD16/CD32; AbD Serotec) for $30 \mathrm{~min}$. BMMs were then stained for $30 \mathrm{~min}$ on ice with A700-conjugated rat anti-mouse LY6G (561236; BD Bioscience), PerCP-Cy5.5-coupled rat anti-mouse CD11b (550993; BD Bioscience), PE/Cy7-conjugated rat anti-mouse LY6C (560593; BD Bioscience), and Alexa Fluor 647coupled rat anti-mouse P2RX7 (MCA4713A647; AbD Serotec). Acquisitions were performed on an LSRII cytometer (BD Bioscience). Expression of P2RX7 by BMM gated for CD11b-PerCP-Cy5.5 and LY6C-Pe/Cy7 expression was analyzed using the FlowJo software.

Cell sorting after light challenge. $C \times 3 \mathrm{cr} 1^{\text {GFP/GFP }}$ and C57BL/6J mice were exposed to green light for $4 \mathrm{~d}$ and directly perfused with PBS. mRNA was extracted from dissected retinal eye cups. Other $C \times 3 \mathrm{cr} 1^{\text {GFP/GFP }}$ mice were exposed to green light for $4 \mathrm{~d}$ and perfused with cold PBS. Eyes were 
dissected (posterior segment of the eyeball) and tissues were dissociated by Neural Tissue Dissociation Kit for $30 \mathrm{~min}$ and filtered in HBSS 10\% bovine serum with a $70 \mathrm{~mm}$ sieve. Cell suspensions were blocked with PBS EDTA $2 \mathrm{~mm}, 3 \%$ rat serum, and 2\% anti-CD16/CD32 for $15 \mathrm{~min}$ on ice. The tissues were labeled $25 \mathrm{~min}$ on ice with anti-CD11b-PerCPCy5.5, Ly6C-PE, and Ly6G-APC (BD Biosciences). Ten percent of the whole-cell suspension was directly lysed. The cells were sorted using a MoFlo Astrios (Beckman Coulter) and cells were directly sorted in lysis buffer to obtain mRNA from CD11b ${ }^{+} \mathrm{Ly}_{6 \mathrm{G}}{ }^{-} \mathrm{Ly}_{6 \mathrm{C}}{ }^{+} \mathrm{GFP}^{\text {low }}$ inflammatory MPs.

TUNEL. TUNEL staining was performed according to the manufacturer's protocol (In Situ Cell Death Detection Kit; Roche Diagnostics). Briefly, retinal flat mount or retina were fixed in 4\% PFA for $30 \mathrm{~min}$ and washed in $1 \times \mathrm{PBS}, \mathrm{pH} 7.3$. Flat mounts were then incubated for $90 \mathrm{~min}$ at $37^{\circ} \mathrm{C}$ with the reaction mixture (In situ Cell Death Detection Kit) and the reaction was stopped by washing with $1 \times$ PBS. Nuclei were stained with Hoechst (Sigma-Aldrich). Flat mount images were captured with a DM 5500 microscope (Leica) or an Olympus Confocal microscope.

Retinal explant cocultures. C57BL/6J- and Cx3cr1 $1^{\text {GFP/GFP }}$-BMMs were seeded on polycarbonate filters floating on DMEM for $2 \mathrm{~h}$. C57BL/6J retinas were prepared and placed with the photoreceptors facing 100,000 adherent BMMs for $18 \mathrm{~h}$ at $37^{\circ} \mathrm{C}$. After $18 \mathrm{~h}$, the explants were carefully removed and TUNEL was performed on the retinal explants. For some experiments, BMMs were treated with BzATP, BBG, or IL-1Ra (Kineret).

ATP measurements. ATP release was quantified by luminometry. The concentration of ATP was measured in supernatants from BMM by using luciferin-luciferase assay (ATPlite Kit; PerkinElmer) according to the manufacturer's instructions, and light production was measured on a luminometer (Infinite M1000; Tecan).

Dye-uptake assays. Cells were washed in $1 \times$ PBS medium, then preincubated in the absence (control) or presence of BzATP $(0.1 \mathrm{~mm})$ at $37^{\circ} \mathrm{C}$ for $30 \mathrm{~min}$. To-pro-3 $(2 \mu \mathrm{M})$ was then added at RT for $10 \mathrm{~min}$. Cells were coverslipped and imaged using a DM 5500 microscope (Leica).

Statistical analysis. GraphPad Prism 6 (GraphPad Software) was used for data analysis and graphic representation. All values are reported as mean \pm SEM (unless specified in the legend). Two-group experiments were analyzed with the nonparametric Mann-Whitney test. One-way ANOVA and Bonferroni multiple-comparison post-tests were used to compare the means of multiple groups. One-way ANOVA and Dunnett's post-tests were used to compare the means of multiple groups to a control value. The $p$ values are indicated in the figures.

\section{Results}

\section{Cx3cr1 ${ }^{\text {GFP/GFP }}$-BMMs constitutively activate their P2RX7 receptor and secrete IL- $1 \beta$ after TLR activation by LPS}

IL- $1 \beta$ activity is rigorously controlled by expression, maturation, and secretion. The Il-1 $\beta$ gene is transcribed after proinflammatory stimuli such as TLR activation (Allan et al., 2005; Simi et al., 2007). The secretion of mature IL- $1 \beta$ necessitates the assembly of the NLRP3 inflammasome (Schroder and Tschopp, 2010). The NLRP 3 inflammasome is activated by pathogens, but can also be activated by host-derived danger signals, such as extracellular ATP, which is associated with injured cells (Mariathasan et al., 2006).

To evaluate if $C \times 3 c r 1$ deficiency influences Il- $1 \beta$ transcription, we first evaluated Il- $1 \beta$ mRNA expression by RT-PCR in CD11b ${ }^{+}-\mathrm{LY}_{6 \mathrm{C}}{ }^{\text {high }}$ BMMs from wild-type $(\mathrm{C} 57 \mathrm{BL} / 6 \mathrm{~J})$ and $C \times 3 c r 1^{G F P / G F P}$ mice with and without LPS stimulation. Il-1 $\beta$ mRNA was significantly increased $18 \mathrm{~h}$ after stimulation in C57BL/6J- and $\mathrm{C} \times 3 \mathrm{cr} 1^{\text {GFP/GFP }}$-BMM, but no genotype-related differences were detectable (Fig. 1A).

To evaluate if $\mathrm{C} \times 3 \mathrm{crl}$ deficiency could influence ATPdependent IL- $1 \beta$ maturation we next analyzed the expression of ligand-gated cation channel P2RX7, a major ATP receptor shown to be involved in NLRP3 inflammasome assembly (Mariathasan et al., 2006). Flow cytometry analysis of $P 2 R X 7$ of BMMs revealed a significant twofold increase in the intensity of surface P2RX7 labeling of $\mathrm{C} \times 3 \mathrm{crr}^{\mathrm{GFP} / \mathrm{GFP}}$-BMMs compared with $\mathrm{C} 57 \mathrm{BL} / 6 \mathrm{~J}-$ BMMs (Fig. $1 B$ ) after $18 \mathrm{~h}$ of BMM culture without LPS.

Activation of the P2RX7 by ATP results in the opening of pannexin channels (Pelegrin and Surprenant, 2006; Bond and Naus, 2014), which can be visualized by the intracellular uptake of a 10 min pulse of carbocyanine fluorescent marker (Qu et al., 2011; Bartlett et al., 2013). To evaluate the P2RX7-dependent channel opening we analyzed the function of the P2RX7 receptor using the red fluorescent marker To-Pro-3 (Fig. 1C). The percentage of To-Pro- $3^{+}$cells had a 1.6-fold increase in Cx3cr1 ${ }^{\text {GFP/GFP }}$-BMMs compared with C57BL/6J-BMMs after $18 \mathrm{~h}$ of BMM culture (Fig. $1 D$ ), suggesting that significantly more P2RX7-dependent channels are open in $C \times 3 c r 1^{\text {GFP/GFP }}$-BMMs. Addition of $0.1 \mathrm{~mm}$ of the BzATP agonist of ATP to C57BL/6JBMMs resulted in a significant increase in To-Pro- $3^{+}$cells reaching the level of $C \times 3 \mathrm{Cr}^{\text {GFP/GFP }}$-BMMs (Fig. 1D).

The opening of pannexin hemichannels can also lead to intracellular ATP release to the extracellular medium (Praetorius and Leipziger, 2009; Qu et al., 2011). Indeed, ATP quantification in the supernatants of unstimulated C57BL/6J- and $C \times 3 \mathrm{cr} 1^{\text {GFP/GFP }}$ BMMs after $18 \mathrm{~h}$ of BMM culture without LPS revealed a significant increase in ATP release from $C \times 3 \mathrm{cr}^{1}{ }^{\text {GFP/GFP }}$ compared with C57BL/6J-BMMs (Fig. 1E). The increased ATP release was not associated with $C \times 3 \mathrm{cr} 1^{\text {GFP/GFP }}$-BMM apoptosis (data not shown). Our results indicate that $C \times 3 \mathrm{cr}^{G F P / G F P}$-BMMs express increased P2RX7, which leads to increased P2RX7-dependent channel opening and ATP release.

To test whether ATP release from $C \times 3 \mathrm{cr}^{\text {GFP/GFP }}$-BMMs autonomously activates the inflammasome and matures IL- $1 \beta$, we measured their ability to secrete IL-1 $\beta$ after TLR activation by LPS without P2RX7 stimulation. Indeed, IL- $1 \beta$ quantification by ELISA in the medium of BMM culture $(18 \mathrm{~h})$ showed that LPS was sufficient to induce IL- $1 \beta$ secretion from $C \times 3 \mathrm{cr} 1^{\text {GFP/GFP }}$ BMMs, but not C57BL/6J-BMMs. Furthermore, inhibition of the P2RX7 by BBG completely prevented the secretion (Fig. $1 F$ ) and shows that P2RX7 activation is necessary for the increased IL- $1 \beta$ secretion from $C \times 3 \mathrm{cr} 1^{G F P / G F P}$-BMMs. In C57BL/6J-BMMs, only the combination of LPS and the ATP analog BzATP led to significant IL- $1 \beta$ secretion (Fig. $1 G$ ). Interestingly, BzATP also led to a further boost of IL- $1 \beta$ secretion in $C \times 3$ cr1 ${ }^{\text {GFP/GFP }}$-BMMs, suggesting that their autonomous P2RX7 activation is only partial and that their IL- $1 \beta$ secretion can further be increased by exogenous ATP stimulation (Fig. $1 H$ ).

In summary, our results demonstrate that $C \times 3 \mathrm{cr} 1^{\text {GFP/GFP }}$-BMMs overexpress P2RX7, release increased amounts of ATP, can partially auto-activate their inflammasome in a P2RX7-dependent manner, and are more sensitive to further ATP stimulation.

\section{BMM differentiation in the presence of photoreceptor outer segments}

We have previously shown that inflammatory Mos that express low levels of CX3CR1 (Geissmann et al., 2003) accumulate subretinally in atrophic regions and in soft drusen of AMD patients (Sennlaub et al., 2013; Levy et al., 2015). Our results revealed that Mos and, particularly, Cx3crl-deficient Mos are toxic to photoreceptors (compared with microglial cells) and that the degeneration observed in vivo in a light-challenge model was mainly mediated by blood-borne Mos (Sennlaub et al., 2013). In the context of sterile neuroinflammation, blood-borne Mos that differentiate into $\mathrm{M} \phi \mathrm{s}$ in the subretinal space are in close contact with phosphatidylserine-rich POSs (Miljanich et al., 1981). Phagocytosis of phosphatidylserine-rich apoptotic bodies has been shown to induce anti-inflammatory mediators and down- 
regulates IL-1 $\beta$ (Fadok et al., 1998; Huynh et al., 2002). To evaluate the influence of POSs on BMM-derived MP differentiation, we prepared C57BL/6J- and CX3 $\mathrm{cr}^{\text {GFP/GFP }}$-BMMs and cultured them for $18 \mathrm{~h}$ with and without POSs prepared from porcine retina.

We first evaluated the expression of the Mannose receptor ( $C d 206)$, which is expressed at low levels during inflammation and at high levels during the resolution of inflammation, to remove inflammatory glycoproteins (Lee et al., 2002; Mantovani et al., 2004). Consistent with an antiinflammatory influence of POSs on $\mathrm{M} \phi \mathrm{s}$, Cd206 was significantly induced by POSs as evaluated by RT-PCR (Fig. 2A). Interestingly, this did not occur in C $x 3 \mathrm{cr} 1^{\text {GFP/GFP }}$-BMMs. Similarly, Il-1ra, which inhibits IL-1 receptor activation, was induced by POSs in C57BL/6J- but not in $C \times 3 c r 1^{G F P / G F P}-B M M s$ (Fig. $2 B$ ). $P 2 r x 7$ transcription was only marginally changed by POSs (Fig. 2C), and POS incubation only slightly reduced the ATP release from $C \times 3 c r 1^{G F P / G F P}$-BMMs into the media (Fig. 2D). Interestingly, POS incubation did not affect $I l-1 \beta$ transcription in C57BL/6J-BMMs and led to a fivefold increase in $\mathrm{C} \times 3 \mathrm{cr} 1^{G F P / G F P}$-BMMs (Fig. $2 E$ ). Culture of BMMs in the presence of POSs or retinal explants for $18 \mathrm{~h}$ lead to a similar regulation of expression $C d 206, I l 1-R a$, $P 2 r x 7$, and $I l-1 \beta$ transcripts (data not shown). When we stimulated C57BL/6Jand $C \times 3 c r 1^{G F P / G F P}$-BMMs additionally with LPS, $I l-1 \beta$ transcription was significantly and similarly induced in both cell types (50-fold; Fig. 2F), although the induction was significantly inhibited compared with LPS stimulation alone (150-fold; Fig. 1A) as previously described (Fadok et al., 1998).

Next we analyzed BMM-derived MPs IL- $1 \beta$ secretion into the medium. C57BL/ $6 \mathrm{~J}-$ and $\mathrm{C} \times 3 \mathrm{cr} 1^{G F P / G F P}$-BMMs were allowed to differentiate for $18 \mathrm{~h}$ into MPs in the presence of POSs. After $18 \mathrm{~h}$ of culture, BMM-derived MPs were stimulated for $3 \mathrm{~h}$ by LPS to induce pro-IL- $1 \beta$ synthesis. LPS-stimulated $C \times 3 c r 1^{\text {GFP/GFP }}$ BMMs secreted significantly more mature IL-1 $\beta$ compared with C57BL/6J-BMMs (Fig. 2G).

Our results show that $C \times 3 c r 1^{G F P / G F P}$ BMMs that differentiated in the presence of POSs maintain their increased ability to mature and secrete IL- $1 \beta$ at significantly higher levels compared with C57BL/6J cells.

\section{Subretinal MPs in light-challenged $C x 3 c r 1^{G F P / G F P}$-mice express IL-1 $\beta$ and P2RX7 in vivo}

The differentiation of blood-borne Mos in the subretinal space in vivo is likely significantly different from the in vitro system.
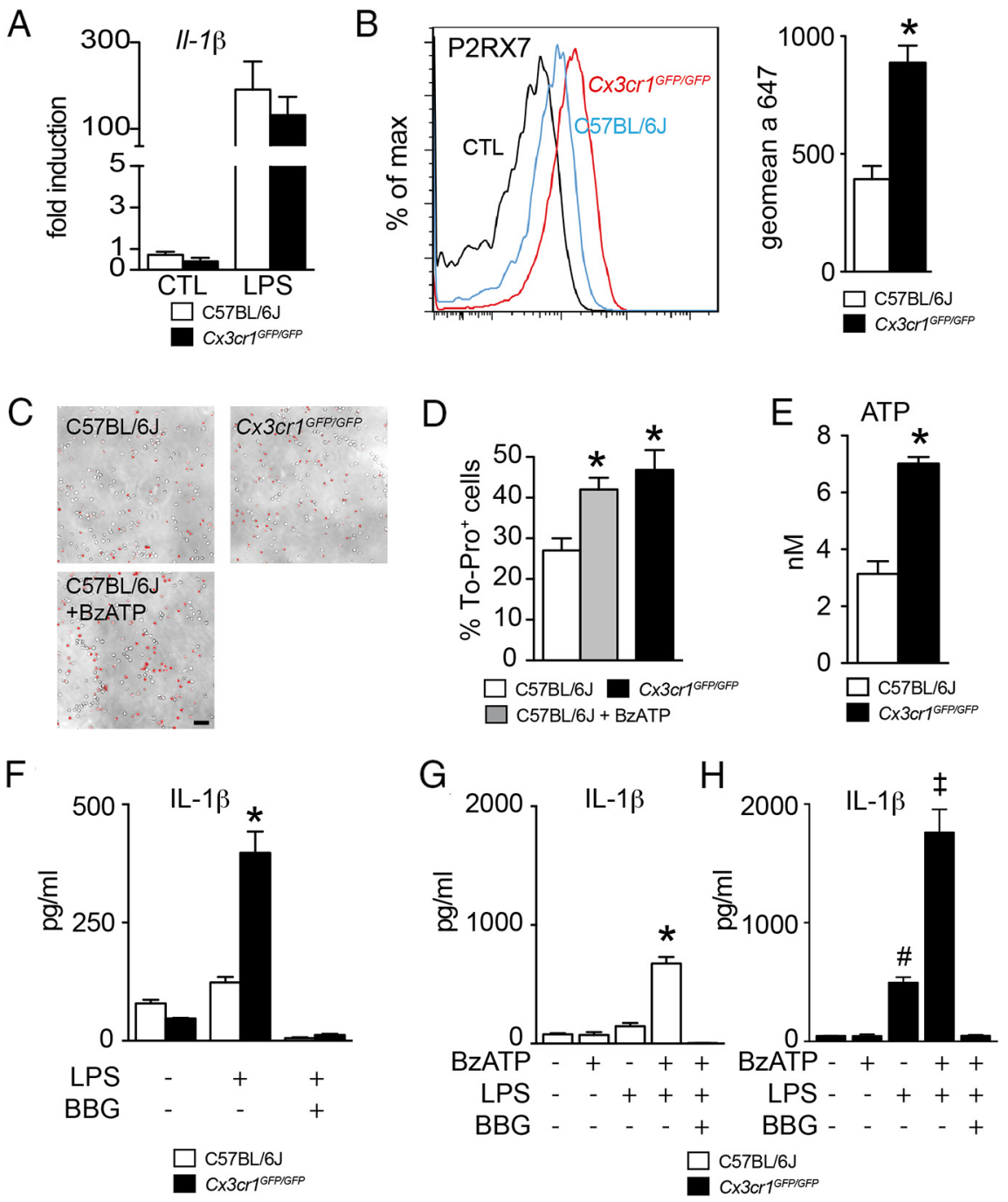

Figure 1. $\quad\left(X 3 C r 7^{G F P / G F P}\right.$-BMMs constitutively activate their P2RX7 receptors and secrete IL-1 $\beta$ after TLR activation by LPS. $A$, Quantitative RT-PCR of II- $1 \beta \mathrm{mRNA}$ normalized with Rps $26 \mathrm{mRNA}$ of C57BL/6J-and C $X 3 \mathrm{cr} 1^{\text {GFP/GFP }}$-BMMs cultured for $18 \mathrm{~h}$ in control conditions or treated with LPS ( $n=4$ per group, one-way ANOVA followed by Bonferroni's post-test, no statistical differences

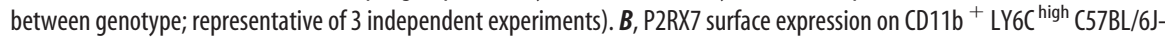
and $C X 3 \mathrm{Cr}^{\text {GFP/GFP }}$-BMMs cultured for $18 \mathrm{~h}$ without LPS was analyzed by flow cytometry (left). The magnitude of P2RX7 surface expression was measured by the geometric mean fluorescence intensity of $(57 \mathrm{BL} / 6)$ - and $\left(\times 3 \mathrm{Cr}^{7 \text { GPP/GFP }}\right.$-BMMs (right) ( $n=3$ per group, ${ }^{*} p<0.05$; Mann-Whitney $U$ test, representative of 3 independent experiments). $C$, Representative images of $(57 \mathrm{BL} / 6 \mathrm{~J}$ -

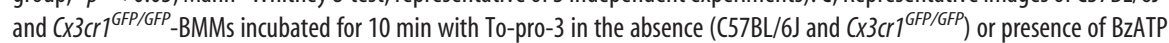

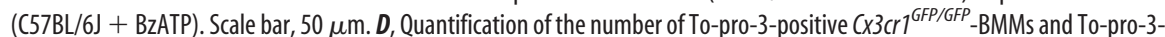
positive (57BL/6J-BMMs incubated in the absence (C57BL/6J) or presence of BzATP (C57BL/6J + BzATP) for $10 \mathrm{~min}(n=5$ per group, ${ }^{*} p<0.05$; one-way ANOVA followed by Dunnett's post-test; (57BL/6J-BMMs as control, representative of 2 independent

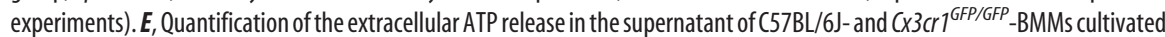
for $18 \mathrm{~h}$ without LPS ( $n=6$ per group, ${ }^{*} p<0.05$; Mann-Whitney $U$ test). $\boldsymbol{F}$, Quantification of IL-1 $\beta$ in the supernatant of C57BL/6)- and CX3cr ${ }^{\text {GFP/GFP }}$-BMMs in control conditions or primed with LPS $(60 \mathrm{ng} / \mathrm{ml})$ or LPS + BBG $(60 \mathrm{ng} / \mathrm{ml}+10 \mu \mathrm{m} ; n=$ $3,{ }^{*} p<0.05$; one-way ANOVA followed by Bonferroni's post-test, representative of 3 independent experiments). $\mathbf{G}, \boldsymbol{H}$, Quantification of IL-1 $\beta$ in the supernatant of $C 57 \mathrm{BL} / 6 \mathrm{G}$-BMMs $(\boldsymbol{G})$ and $\left(X 3 \mathrm{Cr} 1^{\text {GFP/GFP }}\right.$-BMMs $(\boldsymbol{H})$ primed overnight with LPS $(60 \mathrm{ng} / \mathrm{ml})$ and then stimulated with BzATP $(1 \mathrm{~mm})$ in the presence or the absence of BBG $\left(10 \mu \mathrm{m} ; n=5,{ }^{*} p<0.05\right.$; one-way ANOVA followed by Bonferroni's post-test, representative of 2 independent experiments). (TL, control.

Cx3crl deficiency in mice leads to a strong increase of subretinal MP accumulation with age, after light challenge, or laser injury (Combadiére et al., 2007; Sennlaub et al., 2013; Levy et al., 2015). We previously showed that IL- $1 \beta$ protein is increased in the retina of 18-month-old pigmented (C57BL/6J) $C \times 3 c r 1^{\text {GFP/GFP }}$ mice with subretinal MP accumulation and photoreceptor degeneration and in C57BL/6J and Cx3cr ${ }^{\text {GFP/GFP }}$ albino (BALB) mice $24 \mathrm{~h}$ after a light injury, which induces subretinal MP accumulation 


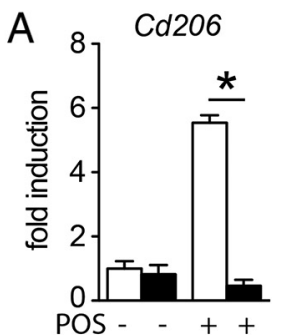

$\mathrm{B}$
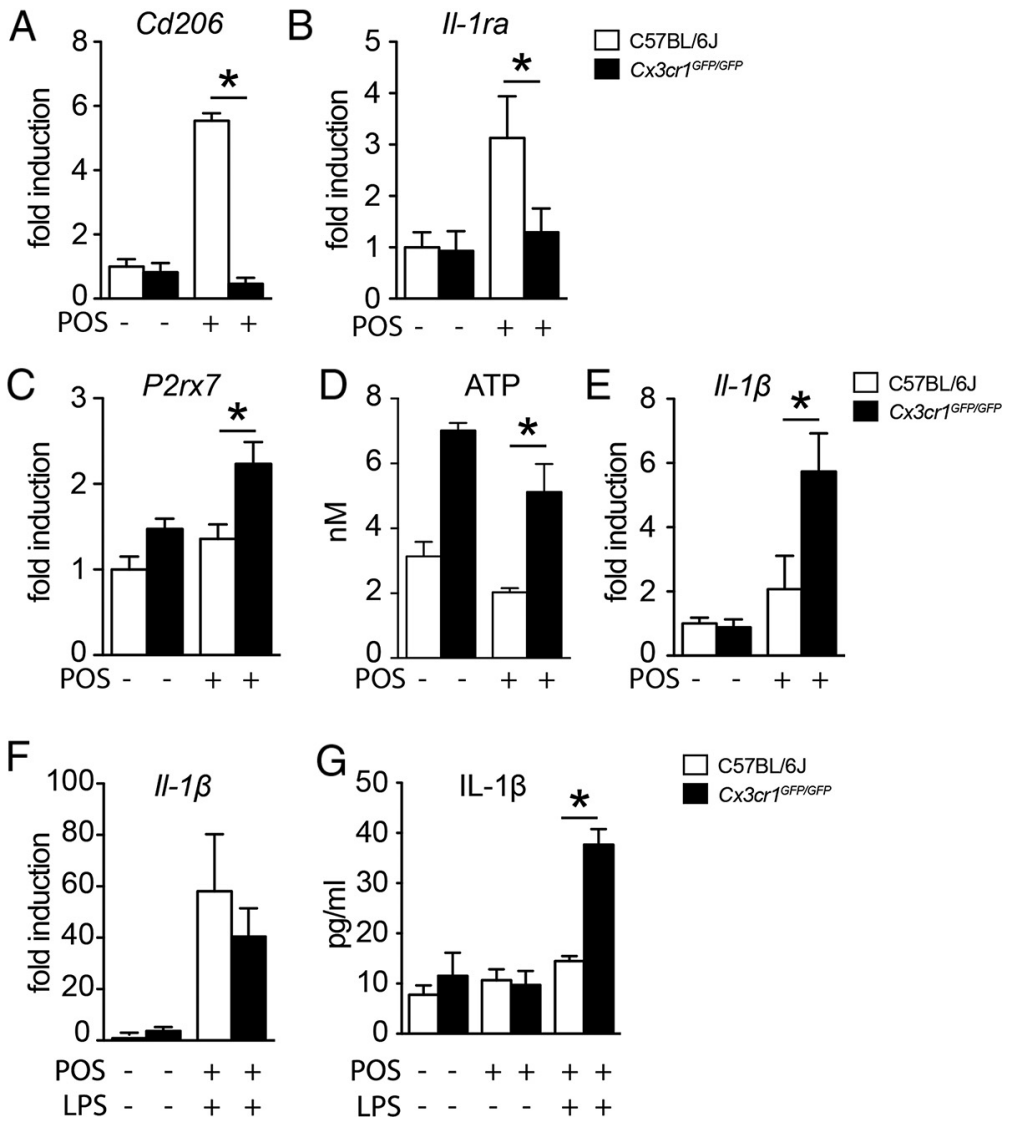

Figure 2. BMM differentiation in the presence of POSs. $A-C$, Quantitative RT-PCR of $C$ d206 $(\boldsymbol{A}), I I-1 R a(\boldsymbol{B})$, and P2rx7 (C) mRNA normalized with Rps $26 \mathrm{mRNA}$ of $\mathrm{C} 57 \mathrm{BL} / 6 \mathrm{~J}$ - and $C \times 3 \mathrm{cr} 1^{\text {GFP/GFP }}$-BMMs cultured for $18 \mathrm{~h}$ with or without POSs $\left(n=5\right.$ per group, ${ }^{*} p<$ 0.01; one-way ANOVA followed by Bonferroni's post-test, representative of 3 independent experiments). D, Quantification of ATP release from $C 57 \mathrm{BL} / 6 \mathrm{~J}$ - and $\mathrm{C} \times 3 \mathrm{Cr} 7^{\text {GFP/GFP }}$-BMMs cultivated for $18 \mathrm{~h}$ with or without POSs ( $n=6$ per group, ${ }^{*} p<0.01$; one-way ANOVA followed by Bonferroni's post-test, representative of 3 independent experiments). $E$, Quantitative RT-PCR of $I-1 \beta$ mRNA

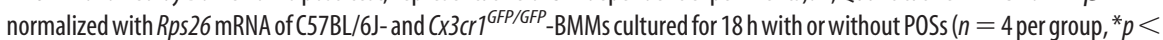
0.01; one-way ANOVA followed by Bonferroni's post-test). $\boldsymbol{F}$, Quantitative RT-PCR of $I I-1 \beta$ mRNA normalized with Rps $26 \mathrm{mRNA}$ of C57BL/6J-and $C \times 3 \mathrm{Cr}^{\text {GFP/GFP }}$-BMMs cultured for $18 \mathrm{~h}$ with or without POSs and LPS ( $60 \mathrm{ng} / \mathrm{ml} ; n=4$ per group). G, Quantification by ELISA of IL- $1 \beta$ in the supernatants of $\left(57 \mathrm{BL} / 6 \mathrm{~J}\right.$ - and $\left(X 3 \mathrm{Cr} 1^{\text {GFP/GFP }}\right.$-BMMs cultured for $18 \mathrm{~h}$ with or without POSs and stimulated or not with LPS ( $60 \mathrm{ng} / \mathrm{ml})$ for $2 \mathrm{~h}\left(n=4\right.$ per group, ${ }^{*} p<0.01$; one-way ANOVA followed by Bonferroni's post-test).

and photoreceptor degeneration in both strains (Lavalette et al., 2011).

Here we first analyzed the kinetics of subretinal accumulation at different time points during the light-challenge protocol, which we developed to induce robust subretinal inflammation and photoreceptor degeneration in pigmented $C \times 3 \mathrm{crr}^{\text {GFP/GFP }}$ C57BL/6J mice but only minor MP accumulation and degeneration in C57BL/6J mice (Sennlaub et al., 2013). We show that subretinal $\mathrm{IBA}^{+}$MPs accumulated significantly more in Cx3 $\mathrm{crl}^{\text {GFP/GFP }}$ mice compared with C57BL/6J animals, reaching a peak at $4 \mathrm{~d}$ (Fig. 3A). Retinal IL- $1 \beta$ protein concentrations, measured by ELISA of retinal homogenates, were similar in nonilluminated 2-month-old C57BL/6J and Cx3cr1 ${ }^{\text {GFP/GFP }}$ mice, but increased in $4 \mathrm{~d}$ light-challenged $C \times 3 c r 1^{\text {GFP/GFP }}$ mice, when the subretinal MP accumulation was at its peak, compared with C57BL/6J mice (Fig. 3B).

In pathological situations, IL- $1 \beta$ can be strongly produced by tissue M $\phi$ s and Mos (Dinarello, 1996), but also by non-myeloid retinal cells, such as Muller cells, astrocytes, or endothelial cells (Hangai et al., 1995; Liu et al., 2012). To further identify the cells responsible for IL- $1 \beta$ production, we compared Il-1 $\beta$ transcription levels of the following: (1) whole-eye lysates
(wE), (2) lysates of retinal cells depleted of $\mathrm{CD}_{11 \mathrm{~b}^{+}} \mathrm{MPs}$ (wE-MP), and (3) CD11b ${ }^{+}$Ly6C $\mathrm{C}^{\text {high }}$ inflammatory Mos sorted by FACS of PBS-perfused $C \times 3 c r 1^{G F P / G F P}$ mice after $4 \mathrm{~d}$ of light challenge. Il-1 $\beta$ mRNA, detected by RTPCR, was greatly enriched in sorted $\mathrm{CD} 11 \mathrm{~b}^{+}$Ly6 $\mathrm{C}^{\text {high }}$ cells when compared with $w E$ (Fig. $3 C$ ). In fact, $I l-1 \beta$ mRNA was not detected in lysates of retinal cells depleted of $C D 11 b^{+}$MPs, suggesting that most Il- $1 \beta$ secretion, which necessitates Il- $1 \beta$ transcription, stemmed from MPs in the light-challenged retina of $C \times 3 c r 1^{G F P / G F P}$ mice. Furthermore, P2rxy mRNA, which we showed is an important factor in IL- $1 \beta$ maturation in $\mathrm{Cx} 3 \mathrm{cr} 1^{\mathrm{GFP} / \mathrm{GFP}}$ MPs, was greatly enriched in Cx3cr1-deficient Ly6C ${ }^{\text {high }}$ MPs compared with the level of P2rx7 transcription in the rest of the retinal cells in vivo (Fig. 3D). Immunohistochemistry of P2XR7 (Fig. 3E, red) on retinal flat mounts of $4 \mathrm{~d}$ light-challenged Cx3cr1 ${ }^{\text {GFP/GFP }}$ mice showed that P2RX7 was located on ramified subretinal cells that costained for the MP marker IBA1 (Fig. 3E, top). IBA1 was visualized using a green fluorescent secondary antibody to increase the fluorescence of GFPexpressing $C \times 3 \mathrm{cr} 1^{G F P / G F P}$-MPs. Highlevel P2RX7 expression was restricted to MPs that had infiltrated the subretinal space, and $\mathrm{IBA}^{+}{ }^{+}$microglial cells of the inner retina only weakly expressed P2RX7 (Fig. 3E, bottom). Similarly, immunohistochemistry of IL- $1 \beta$ (red staining) on RPE/ choroidal flat mounts of $4 \mathrm{~d}$ lightchallenged $C \times 3$ cr1 $1^{G F P / G F P}$ mice showed that IL- $1 \beta$ was located to ramified subretinal cells that costained for the MP marker IBA1 (Fig. 3F), confirming that subretinal MPs were the major IL- $1 \beta$-producing cells in this model.

Our data show that P2XR7 and IL-1 $\beta$ are significantly induced in $C \times 3 c r 1$-deficient subretinal MPs that accumulate in light-challenged $C \times 3 \mathrm{cr} 1^{G F P / G F P}$ mice in vivo.

\section{A P2RX7 antagonist and IL-1Ra inhibit $C x 3^{c r 1} 1^{\text {GFP/GFP }}$-BMM photoreceptor toxicity}

We have previously shown that $C \times 3 c r 1^{\text {GFP/GFP }}$ Mos are particularly toxic to photoreceptors compared with C57BL/6J Mos in an in vitro coculture model (Sennlaub et al., 2013). Here we tested the ability of IL-1Ra, a specific antagonist of IL-1R1, to inhibit CX3cr1 ${ }^{\text {GFP/GFP }}$ BMM-induced photoreceptor cell death in an overlaying retinal explant after $18 \mathrm{~h}$ of coculture in vitro. TUNEL staining of the retinal explants revealed an increased amount of TUNEL $^{+}$nuclei in the outer nuclear layer (which harbors the photoreceptor nuclei) in cocultures with $\mathrm{C} \times 3 \mathrm{crl}^{\text {GFP/GFP }}$-BMMs compared with cocultures with C57BL/6J-BMMs. We show that $\mathrm{TUNEL}^{+}$nuclei were less frequent in $C \times 3 \mathrm{cr} 1^{\text {GFP/GFP }}$-BMMs/retinal cocultures when IL-1Ra was added to the medium (Fig. 4A). Quantification of TUNEL ${ }^{+}$nuclei in the outer nuclear layer revealed a significant 2.7 -fold increase in retina cultured with 
Cx3cr1 $1^{\text {GFP/GFP }}$-BMMs compared with C57BL/6J-BMMs. Addition of IL-1Ra or BBG (the P2XR7 inhibitor that inhibits IL- $1 \beta$ secretion from $C \times 3 c r 1^{G F P / G F P}$ BMMs; Fig. $1 G$ ) completely inhibited the increased photoreceptor toxicity of CX3cr1 ${ }^{\text {GFP/GFP }}$-BMMs (Fig. $4 A, B$ ).

ATP has been shown to be toxic to photoreceptors (Puthussery and Fletcher, 2009; Notomi et al., 2013). As C $\times 3 c r 1^{\text {GFP/GFP }}$-MPs released increased amounts of ATP (Figs. $1 D, 2 D)$, we next tested if ATP was directly toxic to photoreceptor. We cocultured $\mathrm{C} 57 \mathrm{BL} / 6 \mathrm{~J}$ and $P 2 r x 7^{-/-}$retina in the presence of $\mathrm{C} 57 \mathrm{BL} / 6 \mathrm{~J}-$ and $C \times 3 c r 1^{\text {GFP/GFP }}$ BMMs and quantified photoreceptor cell death. Deletion of P2RX7 in the retinal cells did not affect photoreceptor cell death, suggesting that elevated extracellular ATP levels were not directly responsible for the observed photoreceptor cell apoptosis (Fig. 4C). Furthermore, retinal explants cultured in the presence of the ATP agonist BzATP at $100 \mu \mathrm{M}$ did not exhibit toxicity when compared with retinal explants cultured in control conditions (Fig. 4D). P2rx $7^{-/-}$- and C57BL/6JBMMs exhibited similar toxicity when cultured in the presence of $\mathrm{C} 57 \mathrm{BL} / 6 \mathrm{~J}$ retina (Fig. 4C).

The generation of oxidative and nitrosative stress and the secretion of tumor necrosis factor $\alpha$ can also participate in MP neurotoxicity (Srinivasan et al., 2004; Kraft and Harry, 2011; Nakazawa et al., 2011; Wu et al., 2012; Murakami et al., 2013). However, a soluble TNF $\alpha$ receptor, or nitric oxide inhibitors, and antioxidants did not inhibit the photoreceptor apoptosis induced by $C \times 3 \mathrm{cr} 1^{G F P / G F P}$-BMMs in this system (data not shown).

In summary, we show that IL- $1 \beta$ inhibition or inhibition of P2XR7 completely inhibited the CX3crl-associated increased photoreceptor toxicity ex vivo.

BBG and IL-1Ra inhibit subretinal inflammation-associated photoreceptor degeneration in $\mathrm{Cx} 3 \mathrm{cr} 1^{\text {GFP/GFP }}$ - mice

Results presented above show that $C \times 3 \mathrm{cr} 1^{\text {GFP/GFP }}$-BMMs overexpress P2XR7, which facilitates IL- $1 \beta$ maturation and secretion of ATP/P2RX7 dependently. Our in vitro assay demonstrates that P2XR7-dependent IL- $1 \beta$ release from $C \times 3 c r 1^{\text {GFP/GFP }}$-BMMs mediates the increased toxicity of $C \times 3 c r 1^{G F P / G F P}$-BMMs. Furthermore, we showed that IL-1 $\beta$ and P2RX7 are expressed at high levels in subretinal MPs during the light-induced inflammation in $C \times 3 \mathrm{cr} 1^{\text {GFP/GFP }}$-mice in vivo.

To evaluate the possibility of inhibiting inflammationassociated photoreceptor degeneration in $\mathrm{C} \times 3 \mathrm{crl} 1^{\text {GFP/GFP }}$ mice we used the P2RX7 inhibitor BBG and recombinant IL-1Ra. $C \times 3 \mathrm{cr} 1^{\text {GFP/GFP }}$ mice were light challenged from day 0 to 4 and returned to normal animal facility cyclic light conditions. They received an intravitreal injection of PBS, BBG, or IL-1Ra at day 3 (and day 7 for animals kept until day 10). Quantification of subretinal MPs on IBA1-stained choroidal and retinal flat mounts at days 5 and 10 did not reveal any differences in subretinal MP accumulation in BBG-treated animals compared with PBS- treated animals (Fig. 5A,B). However, the number of apoptotic photoreceptor cells in the ONL, visualized on TUNEL-stained retinal flat mounts (Fig. $5 C, D$ ), were decreased by $20 \%$ at day 5 (BBG) and by $50 \%$ at day 10 (Fig. 5D, BBG and IL-1Ra). To investigate whether $\mathrm{P} 2 \mathrm{r} x \mathrm{7}$ inhibition also prevented photoreceptor toxicity of $\mathrm{C} 57 \mathrm{BL} / 6 \mathrm{~J}-\mathrm{MPs}$, we submitted $\mathrm{C} 57 \mathrm{BL} / 6 \mathrm{~J}$ and $P 2 r x 7^{-1-}$ mice to experimental retinal detachment, where subretinal C57BL/6J-MPs have been shown to participate in photoreceptor degeneration (Nakazawa et al., 2007). C57BL/6J and $P 2 r x 7^{-/-}$mice showed no difference in the number of TUNELpositive photoreceptor cells under these conditions (data not shown), suggesting that $P 2 r x 7$ inhibition only inhibits MP toxicity in situations where extracellular ATP is high and/or P2RX7 is expressed at high levels, such as light-challenged $C \times 3 \mathrm{cr} 1$-deficient mice.

In summary, our results show that pharmacological inhibition of P2XR7 or IL- $1 \beta$ significantly inhibits the inflammationassociated photoreceptor degeneration in $\mathrm{Cx} 3 \mathrm{crl} 1$-deficient mice in vivo.

\section{Discussion}

Inflammatory Mos have been shown to contribute to photoreceptor toxicity in photo-oxidative stress models (Rutar et al., 2012; Sennlaub et al., 2013), in the $A b c a 4^{-1-} R d h 8^{-/-}$mouse Stargardt/AMD model (Kohno et al., 2013), in a carboxyethylpyrrole immunization-induced AMD model (Cruz-Guilloty et al., 2013), and in rd10 mice (Guo et al., 2012). The Mo-derived 
A
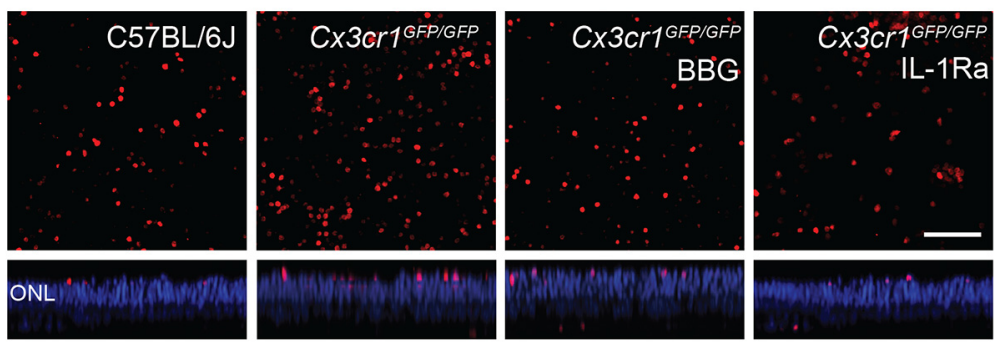

B

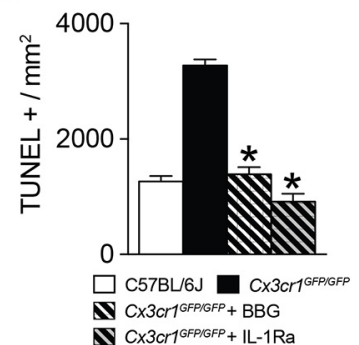

C

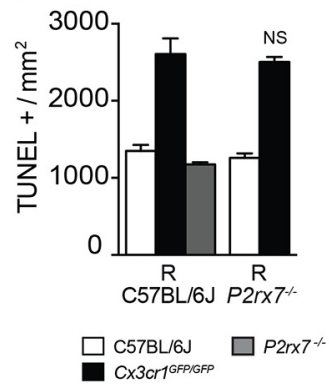

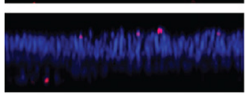

D

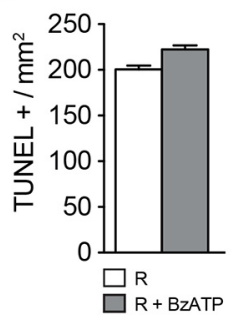

Figure 4. $\quad A P 2 R X 7$ antagonist and IL-1Ra inhibit $C X 3 \mathrm{Cr}^{\text {GFP/GFP }}$-BMM photoreceptor toxicity. $A$, Confocal microscopy of TUNEL

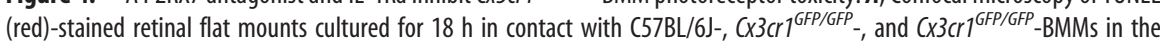
presence of BBG $(10 \mu \mathrm{m})$ or IL-1Ra $(10 \mathrm{mg} / \mathrm{ml})$. Nuclei were stained with Hoechst (blue). Scale bar, $50 \mu \mathrm{m}$. $\boldsymbol{B}$, Quantification of

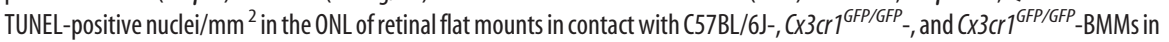
the presence or not of BBG (10 $\mu \mathrm{m})$ or IL-1Ra (10 mg/ml; $n=4$ per group, ${ }^{*} p<0.01$; one-way ANOVA followed by Dunnett's

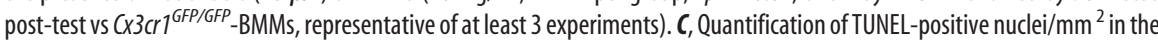

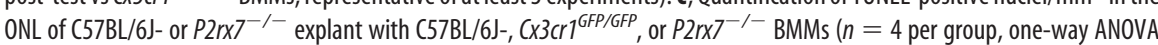
followed by Bonferroni's post-test; NS, no significant differences between $\left(57 \mathrm{BL} / 6 \mathrm{~J}\right.$ and $P 2 r x 7^{-/-}$explant cultured with (X3cr1 ${ }^{\text {GFP/GFP }}$-BMMs). D, Quantification of TUNEL-positive nuclei/mm ${ }^{2}$ in the ONL of retinal explant treated or not with $100 \mu \mathrm{m}$ $\operatorname{BzATP}(n=4$ per experimental group, Mann-Whitney $U$ test, no statistical difference was found). R, retina.

A
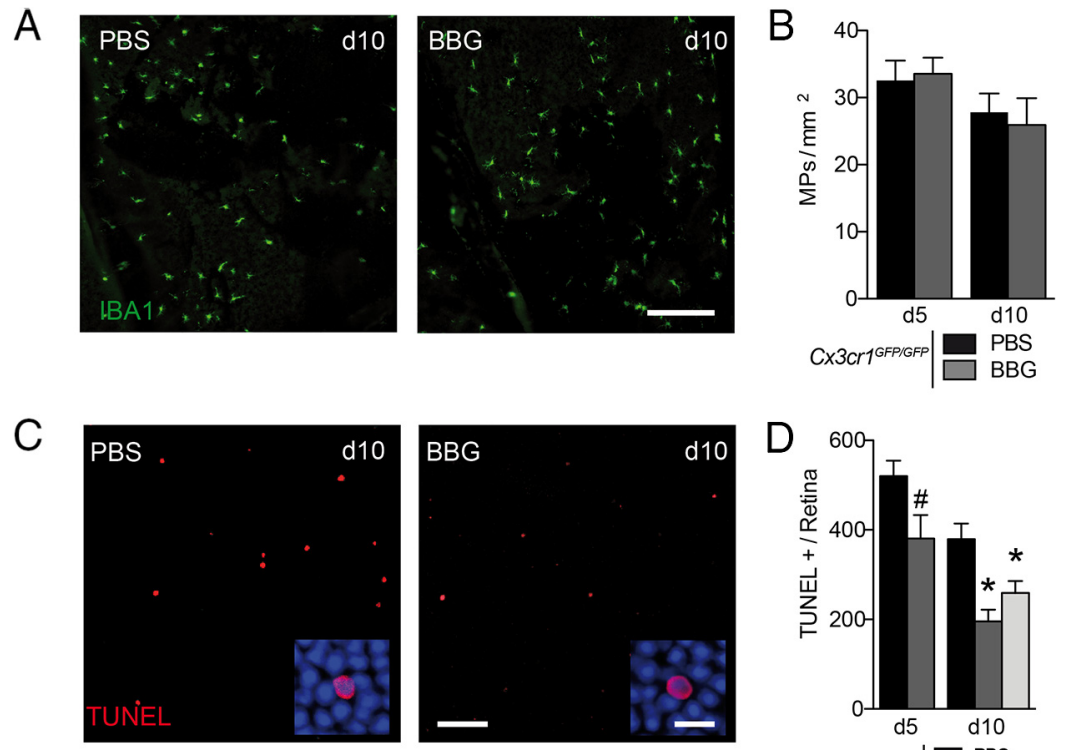

Figure 5. $B B G$ and IL-1Ra inhibit subretinal inflammation-associated photoreceptor degeneration in $C \times 3 c r 1^{G F P / G F P}$ mice. $A$, Representative accumulation of subretinal MP cells (choroidal/RPE flat mounts; green) at day 10 in PBS and BBG (25 mg/L) of $C \times 3 \mathrm{cr} 1^{\text {GFP/GFP }}$ mice treated by intravitreal (IVT) injections at days 3 and 7. Scale bar, $200 \mu \mathrm{m}$. B, MP density in the subretinal space of the light-challenge model of $C \times 3 \mathrm{Cr} 1^{\text {GFP/GFP }}$ mice at days 5 and 10 treated with PBS and BBG at day 3 (animals kept until day 10 received a second IVT on day 7). ( $(n=$ 6 per group, one-way ANOVA followed by Bonferroni's post-test, no differences were found between $C \times 3 \mathrm{Cr} 1^{\text {GFP/GFP }}$ treated with PBS and BBG). C, Confocal microscopy of TUNEL-positive cells (red) through the ONL of a retinal flat mount at day 10 of the light-challenge model of $C \times 3 \mathrm{Cr}^{\text {GFP/GFP }}$ mice treated with PBS or BBG $(25 \mathrm{mg} / \mathrm{L})$ by IVT injections. Scale bars: $50 \mu \mathrm{m}$, Inset, $10 \mu \mathrm{m}$. D, Quantification of the number of TUNEL-positive cell per retina of the light-challenge model of $\left(x 3 \mathrm{cr} 1^{\text {GFP/GFP }}\right.$ mice at days 5 and 10 treated with PBS, BBG $(25 \mathrm{mg} / \mathrm{ml})$, and IL-1Ra $(150 \mathrm{mg} / \mathrm{ml}$ ) at day 3 (animals kept until day 10 received a second IVT on day 7$)$. ( $n=5$ per group, \#p < 0.05; Mann-Whitney Utest day 5 PBS vs day 5 BBG, ${ }^{*} p<0.05$; one-way ANOVA followed by Dunnett's post-tests vs day $10 \mathrm{PBS}$ ).

factors responsible for the photoreceptor toxicity are not well characterized. In the eye, CX3CL1 is constitutively expressed as a transmembrane protein in retinal neurons (Zieger et al., 2014) and physiologically provides a tonic inhibitory signal to CX3CR1-bearing MPs that inhibit the potentially neurotoxic inflammation (Combadière et al., 2007; Ransohoff, 2009). We recently showed in age- and lightchallenged $\mathrm{C} \times 3 \mathrm{cr} 1$-deficient mice that accumulation of infiltrating inflammatory Mos in the subretinal space is responsible for photoreceptor loss (Sennlaub et al., 2013). Here we show that $C \times 3 c r 1^{G F P / G F P}-\mathrm{BMMs}$ overexpress P2XR7 and release increased amounts of ATP compared with C57BL/6JBMMs. In contrast to C57BL/6J-BMMs, $\mathrm{C} \times 3 \mathrm{cr} 1^{\text {GFP/GFP }}$-BMMs spontaneously secrete IL- $1 \beta$ after TLR stimulation via the autonomous activation of P2RX7. We show that IL-1 $\beta$ and $\mathrm{P} 2 \mathrm{RX} 7$ inhibition prevented increased photoreceptor toxicity of Cx3crl $1^{\text {GFP/GFP }}$-BMMs.

The $I l-1 \beta$ gene is transcribed after proinflammatory stimuli, such as TLR activation, and encodes for the pro-IL-1 $\beta$ protein (Allan et al., 2005; Simi et al., $2007)$. The secretion of IL- $1 \beta$ necessitates the NLRP3 inflammasome, which can be activated by extracellular ATP in sterile inflammation (Mariathasan et al., 2006). Our data show that $C \times 3 c r 1^{\text {GFP/GFP }}$-BMMs have increased P2XR7 surface expression, and ATP release into the extracellular medium (Fig. 1). In contrast to C57BL/6JBMMs that necessitate both TLR and P2RX7 stimulation to secrete IL-1 $\beta$ (Fig. 1 ), a single TLR activation is sufficient to allow for the secretion of IL- $1 \beta$ from $C \times 3 \mathrm{cr} 1^{\text {GFP/GFP }}$-BMMs. The secretion of IL- $1 \beta$ by the $C x 3 c r 1^{\text {GFP/GFP }}$-BMMs is mediated by spontaneous ATP release and can be inhibited by P2RX7 antagonist (Fig. 1). Conversely the P2RX7 agonist BzATP further increased the secretion of IL- $1 \beta$ from TLR-stimulated $C \times 3 c r 1^{G F P / G F P}$-BMMs. C $\times 3$ crl ${ }^{G F P / G F P}$-BMMs, in contrast to C57BL/ 6J-BMMs, have the capacity to partly autoactivate the inflammasome in an ATP/ P2RX7-dependent manner and display an increased sensitivity to exogenous ATP. These findings might explain the increase of IL- $1 \beta$ secretion observed in sterile inflammation in the Cx3cr1-deficient brain (Cardona et al., 2006) and age-challenged (Lavalette et al., 2011) and light-challenged Cx3cr1-deficient retina in which subretinal MP accumulate.

ATP has been suggested to directly induce photoreceptor apoptosis in a P2RX7-dependent manner (Puthussery and Fletcher, 2009; Notomi et al., 2013). 
P2RX7 immunoreactivity has been demonstrated at synaptic sites in the outer plexiform layer, but its presynaptic or postsynaptic localization remains controversial (Brändle et al., 1998; Puthussery and Fletcher, 2004; Niyadurupola et al., 2013). P2rx7 mRNA expression is not detected in photoreceptors (Niyadurupola et al., 2013), making a significant P2RX7 expression on photoreceptors unlikely. Our results, using immunohistochemistry on light-challenged $C \times 3 c r 1^{G F P / G F P}$ mice, mainly located P2RX7 to subretinal MPs and not the photoreceptors (Fig. 5). Furthermore, the P2RX7 agonist BzATP $(100 \mu \mathrm{M})$ did not induce photoreceptor apoptosis in retinal explants when subretinal MPs were not present and $P 2 r x 7^{-1-}$ retinal explants did not differ in terms of C57BL/6J and Cx3cr $1^{\text {GFP/GFP }}$-BMM-induced photoreceptor apoptosis. These results suggest that the photoreceptor apoptosis we observed was not due to direct ATP-photoreceptor toxicity, but to P2RX7 activation on $C \times 3 c r 1^{\text {GFP/GFP }}$-BMMs, as the P2RX7 antagonist BBG completely inhibited the photoreceptor toxicity of $C \times 3 c r 1^{G F P / G F P}$-BMMs in the coculture model (Fig. 4) similar to IL-1Ra. Skaper et al. (2006) showed that ATP and BzATP cause neuronal cell injury in rat cortical neurons glial only in the presence of P2RX7-positive MPs, and that deletion of P2RX7 at the surface of MPs inhibited ATP-induced neuronal cell death (Skaper et al., 2006). Our in vitro data suggest that the toxicity of $\mathrm{Cx} 3 \mathrm{cr} 1$-deficient MPs is the result of a combination of spontaneous ATP release from the MPs and increased sensitivity to extracellular ATP. As ATP is abundantly present intracellularly and is released from injured cells during dissection, we were not able to measure the levels of extracellular ATP in our in vivo experiments. However, the fact that BBG and IL-1Ra inhibited photoreceptor apoptosis in light-challenged $C \times 3 \mathrm{cr} 1^{\text {GFP/GFP }}$ mice shows that both, extracellular ATP and IL- $1 \beta$ secretion, play an important role in vivo. In C57BL/6J-MPs the toxicity might be limited by the level of exogenous ATP available at the site of sterile inflammation and their lower sensitivity, due to lower P2RX7 expression in these experimental conditions. In the human disease it has been shown that wet AMD patients exhibit elevated vitreous ATP concentration, which has been suggested to participate in photoreceptor cell death (Puthussery and Fletcher, 2009; Notomi et al., 2013), and dying cells likely release ATP in GA. These high concentrations in AMD patients might be sufficient to trigger IL- $1 \beta$ secretion from subretinally accumulated pro-inflammatory Mos in humans.

When Mos differentiate into M $\phi$ s in the subretinal space they are in close contact with POSs. Phosphatidylserine-rich POSs (Miljanich et al., 1981) have been shown to induce antiinflammatory mediators and downregulate $I l-1 \beta$ (Fadok et al., 1998; Huynh et al., 2002). In contrast to C57BL/6J-BMMs, POSs did not alter the capacity of $C \times 3 c r 1^{G F P / G F P}$-BMMs to release ATP and to auto-activate IL- $1 \beta$ maturation after LPS stimulation alone, but they reduced the levels of induction. Interestingly, CX3cr1 deficiency also blunted the POS-dependent induction of anti-inflammatory factors such as Cd206 and Il-1 ra observed in C57BL/6J-BMMs. We recently showed that CX3cr1 deficiency in myeloid cells impairs their elimination from the subretinal space by the retinal pigment epithelial cells (Levy et al., 2015). The observed photoreceptor cell loss in these mice is likely the result of the increased survival of subretinal $\mathrm{C} \times 3 \mathrm{cr} 1$-deficient MPs and their impaired capacity to differentiate to an anti-inflammatory phenotype.

MP-derived IL-1 $\beta$ has been shown to induce neuronal cell death in a variety of models of acute injury and age-related neurodegenerative diseases in the brain (Allan et al., 2005; Shaftel et al., 2008) and in models of retinal ischemia (Kido et al., 2001;
Yoneda et al., 2001). Similarly, we show here that the excessive photoreceptor toxicity of $C x 3 c r 1^{G F P / G F P}$-BMMs was completely inhibited by the IL-1 inhibitor IL-1Ra ex vivo and in vivo (Figs. 4, 5 ). This protective effect seems to be restricted to conditions in which collateral damage from neuroinflammation plays a major role in neurotoxicity, as IL-Ra was not able to reverse photoreceptor degeneration in albino rats or albino $\mathrm{C} \times 3 \mathrm{cr} 1^{-/-}$mice subjected to toxic light intensities (Lavalette et al., 2011).

In vivo, we show that IL- $1 \beta$ and $\mathrm{P} 2 \mathrm{RX} 7$ are strongly expressed by subretinal MPs that accumulate in light-challenged $C \times 3 \mathrm{cr} 1^{\text {GFP/GFP }}$ mice. Intravitreal injections of IL-1Ra or the specific P2RX7 inhibitor BBG, significantly inhibited photoreceptor apoptosis similar to its effect in models of subretinal hemorrhage (Notomi et al., 2013), glaucoma (Niyadurupola et al., 2013), cerebral ischemia/ reperfusion injury (Sugiyama et al., 2010; Arbeloa et al., 2012; Chu et al., 2012; Yu et al., 2013), and Huntingdon's disease (DíazHernández et al., 2009). Interestingly and contrary to neuroinflammation in cerebral ischemia/reperfusion injury (Chu et al., 2012; Yu et al., 2013), P2XR7 inhibition did not influence the accumulation of $C \times 3 c r 1^{\text {GFP/GFP }}$-MPs, suggesting that ATP does not contribute to MP recruitment in this model.

The results of our study provide an explanation for the increased IL- $1 \beta$ secretion observed in CX3cr1-deficient MPs (Cardona et al., 2006). They suggest that P2RX7 inhibition protects from subretinal inflammation-associated photoreceptor degeneration in diseases such as GA, where inflammatory Mos accumulate (Sennlaub et al., 2013) and extracellular ATP from dying cells is likely abundant. P2RX7 has also been shown to activate the inflammasome in the RPE in a model of AluRNA-induced RPE degeneration via IL-18 suggested to play an important role in GA (Kerur et al., 2013). P2RX7 inhibitors, therefore, might be a promising therapeutic target to inhibit GA lesion expansion, as it might prevent further RPE cell death, and IL-1 $\beta$ and P2RX7 inhibitors might help prevent inflammation-associated photoreceptor loss.

\section{References}

Allan SM, Tyrrell PJ, Rothwell NJ (2005) Interleukin-1 and neuronal injury. Nat Rev Immunol 5:629-640. CrossRef Medline

Arbeloa J, Pérez-Samartín A, Gottlieb M, Matute C (2012) P2X7 receptor blockade prevents ATP excitotoxicity in neurons and reduces brain damage after ischemia. Neurobiol Dis 45:954-961. CrossRef Medline

Bartlett R, Yerbury JJ, Sluyter R (2013) P2X7 receptor activation induces reactive oxygen species formation and cell death in murine EOC13 microglia. Mediators Inflamm 2013:271813. CrossRef Medline

Bond SR, Naus CC (2014) The pannexins: past and present. Front Physiol 5:58. CrossRef Medline

Brändle U, Kohler K, Wheeler-Schilling TH (1998) Expression of the P2X7receptor subunit in neurons of the rat retina. Brain Res Mol Brain Res 62:106-109. CrossRef Medline

Cardona AE, Pioro EP, Sasse ME, Kostenko V, Cardona SM, Dijkstra IM, Huang D, Kidd G, Dombrowski S, Dutta R, Lee JC, Cook DN, Jung S, Lira SA, Littman DR, Ransohoff RM (2006) Control of microglial neurotoxicity by the fractalkine receptor. Nat Neurosci 9:917-924. CrossRef Medline

Chow A, Brown BD, Merad M (2011) Studying the mononuclear phagocyte system in the molecular age. Nat Rev Immunol 11:788-798. CrossRef Medline

Chu K, Yin B, Wang J, Peng G, Liang H, Xu Z, Du Y, Fang M, Xia Q, Luo B (2012) Inhibition of $\mathrm{P} 2 \mathrm{X} 7$ receptor ameliorates transient global cerebral ischemia/reperfusion injury via modulating inflammatory responses in the rat hippocampus. J Neuroinflammation 9:69. CrossRef Medline

Combadière C, Feumi C, Raoul W, Keller N, Rodéro M, Pézard A, Lavalette S, Houssier M, Jonet L, Picard E, Debré P, Sirinyan M, Deterre P, Ferroukhi T, Cohen SY, Chauvaud D, Jeanny JC, Chemtob S, Behar-Cohen F, Sennlaub F (2007) CX3CR1-dependent subretinal microglia cell accumula- 
tion is associated with cardinal features of age-related macular degeneration. J Clin Invest 117:2920-2928. CrossRef Medline

Conductier G, Blondeau N, Guyon A, Nahon JL, Rovère C (2010) The role of monocyte chemoattractant protein MCP1/CCL2 in neuroinflammatory diseases. J Neuroimmunol 224:93-100. CrossRef Medline

Cruz-Guilloty F, Saeed AM, Echegaray JJ, Duffort S, Ballmick A, Tan Y, Betancourt M, Viteri E, Ramkhellawan GC, Ewald E, Feuer W, Huang D, Wen R, Hong L, Wang H, Laird JM, Sene A, Apte RS, Salomon RG, Hollyfield JG, et al. (2013) Infiltration of proinflammatory $\mathrm{m} 1$ macrophages into the outer retina precedes damage in a mouse model of agerelated macular degeneration. Int J Inflam 2013:503725. CrossRef Medline

Díaz-Hernández M, Díez-Zaera M, Sánchez-Nogueiro J, Gómez-Villafuertes R, Canals JM, Alberch J, Miras-Portugal MT, Lucas JJ (2009) Altered P2X7-receptor level and function in mouse models of Huntington's disease and therapeutic efficacy of antagonist administration. FASEB J 23: 1893-1906. CrossRef Medline

Dinarello CA (1996) Biologic basis for interleukin-1 in disease. Blood 87: 2095-2147. Medline

Fadok VA, Bratton DL, Konowal A, Freed PW, Westcott JY, Henson PM (1998) Macrophages that have ingested apoptotic cells in vitro inhibit proinflammatory cytokine production through autocrine/paracrine mechanisms involving TGF-beta, PGE2, and PAF. J Clin Invest 101:890898. CrossRef Medline

Galea I, Bechmann I, Perry VH (2007) What is immune privilege (not)? Trends Immunol 28:12-18. CrossRef Medline

Geissmann F, Jung S, Littman DR (2003) Blood monocytes consist of two principal subsets with distinct migratory properties. Immunity 19:71-82. CrossRef Medline

Guo C, Otani A, Oishi A, Kojima H, Makiyama Y, Nakagawa S, Yoshimura N (2012) Knockout of ccr2 alleviates photoreceptor cell death in a model of retinitis pigmentosa. Exp Eye Res 104:39-47. CrossRef Medline

Gupta N, Brown KE, Milam AH (2003) Activated microglia in human retinitis pigmentosa, late-onset retinal degeneration, and age-related macular degeneration. Exp Eye Res 76:463-471. CrossRef Medline

Hangai M, Yoshimura N, Yoshida M, Yabuuchi K, Honda Y (1995) Interleukin-1 gene expression in transient retinal ischemia in the rat. Invest Ophthalmol Vis Sci 36:571-578. Medline

Huynh ML, Fadok VA, Henson PM (2002) Phosphatidylserine-dependent ingestion of apoptotic cells promotes TGF-betal secretion and the resolution of inflammation. J Clin Invest 109:41-50. CrossRef Medline

Kerur N, Hirano Y, Tarallo V, Fowler BJ, Bastos-Carvalho A, Yasuma T, Yasuma R, Kim Y, Hinton DR, Kirschning CJ, Gelfand BD, Ambati J (2013) TLR-independent and P2X7-dependent signaling mediate Alu RNA-induced NLRP3 inflammasome activation in geographic atrophy. Invest Ophthalmol Vis Sci 54:7395-7401. CrossRef Medline

Kido $\mathrm{N}$, Inatani $\mathrm{M}$, Honjo $\mathrm{M}$, Yoneda $\mathrm{S}$, Hara $\mathrm{H}$, Miyawaki N, Honda $\mathrm{Y}$, Tanihara H (2001) Dual effects of interleukin-1beta on N-methyl-Daspartate-induced retinal neuronal death in rat eyes. Brain Res 910:153162. CrossRef Medline

Klein R, Peto T, Bird A, Vannewkirk MR (2004) The epidemiology of agerelated macular degeneration. Am J Ophthalmol 137:486-495. CrossRef Medline

Kohno H, Chen Y, Kevany BM, Pearlman E, Miyagi M, Maeda T, Palczewski K, Maeda A (2013) Photoreceptor proteins initiate microglial activation via toll-like receptor 4 in retinal degeneration mediated by all-transretinal. J Biol Chem 288:15326-15341. CrossRef Medline

Kraft AD, Harry GJ (2011) Features of microglia and neuroinflammation relevant to environmental exposure and neurotoxicity. Int J Environ Res Public Health 8:2980-3018. CrossRef Medline

Lavalette S, Raoul W, Houssier M, Camelo S, Levy O, Calippe B, Jonet L, Behar-Cohen F, Chemtob S, Guillonneau X, Combadière C, Sennlaub F (2011) Interleukin-1beta inhibition prevents choroidal neovascularization and does not exacerbate photoreceptor degeneration. Am J Pathol 178:2416-2423. CrossRef Medline

Lee SJ, Evers S, Roeder D, Parlow AF, Risteli J, Risteli L, Lee YC, Feizi T, Langen H, Nussenzweig MC (2002) Mannose receptor-mediated regulation of serum glycoprotein homeostasis. Science 295:1898-1901. CrossRef Medline

Levy O, Calippe B, Lavalette S, Hu SJ, Raoul W, Dominguez E, Housset M, Paques M, Sahel JA, Bemelmans AP, Combadiere C, Guillonneau X, Sennlaub F (2015) Apolipoprotein E promotes subretinal mononuclear phagocyte survival and chronic inflammation in age-related macular degeneration. EMBO Mol Med 7:211-226. CrossRef Medline

Liu Y, Biarnés Costa M, Gerhardinger C (2012) IL-1beta is upregulated in the diabetic retina and retinal vessels: cell-specific effect of high glucose and IL-1beta autostimulation. PLoS One 7:e36949. CrossRef Medline

Mantovani A, Sica A, Sozzani S, Allavena P, Vecchi A, Locati M (2004) The chemokine system in diverse forms of macrophage activation and polarization. Trends Immunol 25:677-686. CrossRef Medline

Mariathasan S, Weiss DS, Newton K, McBride J, O’Rourke K, Roose-Girma M, Lee WP, Weinrauch Y, Monack DM, Dixit VM (2006) Cryopyrin activates the inflammasome in response to toxins and ATP. Nature 440: 228-232. CrossRef Medline

Miljanich GP, Nemes PP, White DL, Dratz EA (1981) The asymmetric transmembrane distribution of phosphatidylethanolamine, phosphatidylserine, and fatty acids of the bovine retinal rod outer segment disk membrane. J Membr Biol 60:249-255. CrossRef Medline

Molday LL, Molday RS (1987) Glycoproteins specific for the retinal rod outer segment plasma membrane. Biochim Biophys Acta 897:335-340. Medline

Murakami Y, Notomi S, Hisatomi T, Nakazawa T, Ishibashi T, Miller JW, Vavvas DG (2013) Photoreceptor cell death and rescue in retinal detachment and degenerations. Prog Retin Eye Res 37:114-140. CrossRef Medline

Nakazawa T, Hisatomi T, Nakazawa C, Noda K, Maruyama K, She H, Matsubara A, Miyahara S, Nakao S, Yin Y, Benowitz L, Hafezi-Moghadam A, Miller JW (2007) Monocyte chemoattractant protein 1 mediates retinal detachment-induced photoreceptor apoptosis. Proc Natl Acad Sci U S A 104:2425-2430. CrossRef Medline

Nakazawa T, Kayama M, Ryu M, Kunikata H, Watanabe R, Yasuda M, Kinugawa J, Vavvas D, Miller JW (2011) Tumor necrosis factor-alpha mediates photoreceptor death in a rodent model of retinal detachment. Invest Ophthalmol Vis Sci 52:1384-1391. CrossRef Medline

Niyadurupola N, Sidaway P, Ma N, Rhodes JD, Broadway DC, Sanderson J (2013) P2X7 receptor activation mediates retinal ganglion cell death in a human retina model of ischemic neurodegeneration. Invest Ophthalmol Vis Sci 54:2163-2170. CrossRef Medline

Notomi S, Hisatomi T, Murakami Y, Terasaki H, Sonoda S, Asato R, Takeda A, Ikeda Y, Enaida H, Sakamoto T, Ishibashi T (2013) Dynamic increase in extracellular ATP accelerates photoreceptor cell apoptosis via ligation of P2RX7 in subretinal hemorrhage. PLoS One 8:e53338. CrossRef Medline

Pelegrin P, Surprenant A (2006) Pannexin-1 mediates large pore formation and interleukin-1beta release by the ATP-gated P2X7 receptor. EMBO J 25:5071-5082. CrossRef Medline

Praetorius HA, Leipziger J (2009) ATP release from non-excitable cells. Purinergic Signal 5:433-446. CrossRef Medline

Puthussery T, Fletcher E (2009) Extracellular ATP induces retinal photoreceptor apoptosis through activation of purinoceptors in rodents. J Comp Neurol 513:430-440. CrossRef Medline

Puthussery T, Fletcher EL (2004) Synaptic localization of P2X7 receptors in the rat retina. J Comp Neurol 472:13-23. CrossRef Medline

Qu Y, Misaghi S, Newton K, Gilmour LL, Louie S, Cupp JE, Dubyak GR, Hackos D, Dixit VM (2011) Pannexin-1 is required for ATP release during apoptosis but not for inflammasome activation. J Immunol 186:65536561. CrossRef Medline

Ransohoff RM (2009) Chemokines and chemokine receptors: standing at the crossroads of immunobiology and neurobiology. Immunity 31:711721. CrossRef Medline

Rutar M, Natoli R, Provis JM (2012) Small interfering RNA-mediated suppression of Ccl2 in Muller cells attenuates microglial recruitment and photoreceptor death following retinal degeneration. J Neuroinflammation 9:221. CrossRef Medline

Sarks SH (1976) Ageing and degeneration in the macular region: a clinicopathological study. Br J Ophthalmol 60:324-341. CrossRef Medline

Schroder K, Tschopp J (2010) The inflammasomes. Cell 140:821-832. CrossRef Medline

Sennlaub F, Auvynet C, Calippe B, Lavalette S, Poupel L, Hu SJ, Dominguez E, Camelo S, Levy O, Guyon E, Saederup N, Charo IF, Rooijen NV, Nandrot E, Bourges JL, Behar-Cohen F, Sahel JA, Guillonneau X, Raoul W, Combadiere C (2013) CCR2(+) monocytes infiltrate atrophic lesions in agerelated macular disease and mediate photoreceptor degeneration in 
experimental subretinal inflammation in $\mathrm{Cx} 3 \mathrm{cr} 1$ deficient mice. EMBO Mol Med 5:1775-1793. CrossRef Medline

Shaftel SS, Griffin WS, O'Banion MK (2008) The role of interleukin-1 in neuroinflammation and Alzheimer disease: an evolving perspective. J Neuroinflammation 5:7. CrossRef Medline

Simi A, Lerouet D, Pinteaux E, Brough D (2007) Mechanisms of regulation for interleukin-1beta in neurodegenerative disease. Neuropharmacology 52:1563-1569. CrossRef Medline

Skaper SD, Facci L, Culbert AA, Evans NA, Chessell I, Davis JB, Richardson JC (2006) P2X(7) receptors on microglial cells mediate injury to cortical neurons in vitro. Glia 54:234-242. CrossRef Medline

Srinivasan B, Roque CH, Hempstead BL, Al-Ubaidi MR, Roque RS (2004) Microglia-derived pronerve growth factor promotes photoreceptor cell death via p75 neurotrophin receptor. J Biol Chem 279:41839-41845. CrossRef Medline

Streilein JW (2003) Ocular immune privilege: therapeutic opportunities from an experiment of nature. Nat Rev Immunol 3:879-889. CrossRef Medline
Sugiyama T, Oku H, Shibata M, Fukuhara M, Yoshida H, Ikeda T (2010) Involvement of $\mathrm{P} 2 \mathrm{X} 7$ receptors in the hypoxia-induced death of rat retinal neurons. Invest Ophthalmol Vis Sci 51:3236-3243. CrossRef Medline

Wolf Y, Yona S, Kim KW, Jung S (2013) Microglia, seen from the CXCR1 angle. Front Cell Neurosci 7:26. CrossRef Medline

Wu GS, Jiang M, Liu YH, Nagaoka Y, Rao NA (2012) Phenotype of transgenic mice overexpressed with inducible nitric oxide synthase in the retina. PLoS One 7:e43089. CrossRef Medline

Yoneda S, Tanihara H, Kido N, Honda Y, Goto W, Hara H, Miyawaki N (2001) Interleukin-1beta mediates ischemic injury in the rat retina. Exp Eye Res 73:661-667. CrossRef Medline

Yu Q, Guo Z, Liu X, Ouyang Q, He C, Burnstock G, Yuan H, Xiang Z (2013) Block of P2X7 receptors could partly reverse the delayed neuronal death in area $\mathrm{CAl}$ of the hippocampus after transient global cerebral ischemia. Purinergic Signal 9:663-675. CrossRef Medline

Zieger M, Ahnelt PK, Uhrin P (2014) CX3CL1 (fractalkine) protein expression in normal and degenerating mouse retina: in vivo studies. PLoS One 9:e106562. CrossRef Medline 